\title{
Apricot Culture in Container for Earliness
}

\section{Sara DEMIRAL ${ }^{1}$, Salih ÜLGER 2}

${ }^{1}$ Regional Agriculture Department, Antalya-Turkey, ${ }^{2}$ Department of Horticulture, Faculty of Agriculture, Akdeniz University, Antalya-Turkey ${ }^{1}$ https://orcid.org/0000-0003-3518-7226, ${ }^{2}$ https://orcid.org/0000-0002-3314-2369

\begin{abstract}
The aim of this research was to induce earliness in apricot cultivars Aurora, Ninfa and Roxana grown in containers in greenhouse under the Antalya environmental conditions. The plants were planted in 30 L black plastic containers filled with peat: manure (\%60:\%40) mixture. The plants were treated with control, Dormex 2.5\%, 200 ppm gibberellic acid $\left(\mathrm{GA}_{3}\right)$ and artificial chilling (30 days/720 hours at 5 ${ }^{\circ} \mathrm{C}$ ). Then they were transferred into the greenhouse, and kept there until harvest. During the vegetation periods, some phenological and pomological parameters were determined. Among the apricot cultivars, Ninfa treated with Dormex \%2.5 was the earliest one in flowering and harvesting time. On the other hand, artificial chilled Ninfa was the best in terms of fruit set ratio and yield. The better results were recorded in respect to soluble solid content in Roxana cultivars treated with $200 \mathrm{ppm} \mathrm{GA}$. The results showed that selection of suitable cultivars such as Ninfa for Antalya climatic conditions in apricots seemed quite important. Aurora and Roxana apricots were poor in fruit sets in control plants. The low production could be related to inadequate chill requirements. About 7 to 10 days earliness in fruit harvesting can be obtained in selected apricot cultivars under the same conditions when all the required treatments and cultivation practices are properly followed.
\end{abstract}

\section{Saksıda Erkenci Kayısı Yetiştiriciliği}

\section{ÖZET}

Araştırmanın amacı, Antalya ekolojik koşullarında plastik serada saksıda yetişen Aurora, Ninfa ve Roxana kayısı çeşitlerinde erkenciliği sağlamaktır. Bitkiler içerisinde \%60 torf:\%40 çiftlik gübresi karışımı bulunan 30 litrelik saksılarda yetiştirilmiştir. Bitkilere kontrol, \%2.5 Dormex, 200 ppm GA 3 ve soğuk depoda (30 gün/720 saat) uygulamaları yapılmıştır. Daha sonra plastik seralara taşınmışlar ve meyve hasatları yapılıncaya kadar plastik serada bekletilmişlerdir. Deneme süresince bitkilerde bazı fenolojik ve pomolojik özellikler belirlenmiştir. Kayısı çeşitleri arasında, en erken çiçeklenme ve hasada gelme bakımından \%2.5 Dormex uygulanmış Ninfa olmuştur. Diğer taraftan, soğukta bekletilmiş Ninfa, meyve tutumu ve bitki başına verim bakımından en iyi sonuçları vermiştir.

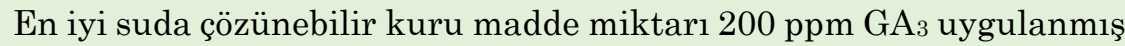
Roxana çeşidinden elde edilmiştir. Araştırma sonuçları, Antalya ekolojik koşulları için Ninfa gibi soğuklama ihtiyacı düşük çeşitlerin seçiminin önemliliğini göstermiştir. Aurora ve Roxana çeşitlerinin kontrol bitkileri meyve verimleri düşük olmuştur. Bu durum soğuklamanın yeterli karşılanamaması ile ilgili olabilir. Aynı uygulamalar yapılmasına rağmen, sera koşullarında yetişen kayısılarda dış koşullarda ortamda yetişenlere göre yaklaşık 7-10 gün erkencilik sağlanmıştır.

\section{Research Article}

$\begin{array}{ll}\text { Article History } & \\ \text { Received } & : 06.05 .2019 \\ \text { Accepted } & : 19.07 .2019\end{array}$

Keywords

Apricot

Container growing

Earliness

\section{Araştırma Makalesi}

Makale Tarihçesi

Geliş Tarihi : 06.05.2019

Kabul Tarihi : 19.07 .2019

\section{Anahtar Kelimeler}

Kayısı

Erkencilik

Saksıda yetiştiricilik

To Cite: Demiral S, Ülger S 2019. Apricot Culture in Container for Earliness. KSU J. Agric Nat 22(Suppl 2): 330-336. DOI: 10.18016/ksutarimdoga.vi.561013. 


\section{INTRODUCTION}

Turkey is an important apricot producing country in the world with 985.000 tons production and 64.000 tons exported as table consumption (Anonymous, 2018). Most of the world table apricot exports are made by apricot producing Mediterranean countries (Gülcan et al., 2000). Earliness in apricot production is important to increase producer income (Ayanoğlu and Kaşka, 1993). Most of the table apricot production in Turkey takes place nearby Mediterranean coast (Son, 2018). The most important limiting factors for apricot growing in the subtropical region is the chilling requirements (Aşkın, 1989; Zhuang et al., 2016).

Artificial chilled apricot (cv. Canino and Sayeb) and sweet cherry ( $\mathrm{Cv}$. Burlat and pollinators) in plastic containers filled with volcanic tuff were grown in Hamat Gader in the Jordan valley area at $100 \mathrm{~m}$ below to the sea level. The apricot trees bloomed (early January) earlier than sweet cherries (late January), and they ripened 7 and 5 weeks earlier, respectively that of the corresponding cultivars in the coastal plain of Israel (Ran and Erez, 1993).

Different hydrogen cyanamide $\left(\mathrm{H}_{2} \mathrm{CN}_{2}\right)$ concentrations were sprayed to Trinto apricot cultivar grown in containers. After application, some trees were grown in controlled conditions $\left(23^{\circ} \mathrm{C} \pm 1\right)$ for $15-20$ days, and others outside. Higher concentrations of $\mathrm{H}_{2} \mathrm{CN}_{2}$ inhibited flower bud break, but lowest concentration promoted flower bud break. Leaf buds showed better $\mathrm{HCN}$ tolerance than flower buds treated later and at higher concentrations (Bartolini et al., 1997).

The performance of 42 apricot varieties was studied in the greenhouse, the best results were obtained from 9803 type. Chilling requirement of 9803 types was 490 chilling unit (CU). In this type, the fruits were ripened in mid-April, flower initiation was started 10-15 days after harvest, and suitable pruning types was V shape (Xiang He et al., 2004).

$\mathrm{H}_{2} \mathrm{CN}_{2}$ has many effects on dormancy breaking, early and uniform bud break and chilling requirements in almond, apple, actinidia, fig, grapevine, peach, persimmon and plum. $\mathrm{H}_{2} \mathrm{CN}_{2}$ also reduce catalase activity (Shulman et al., 1986).

Chilling requirements of peach trees grown in small containers filled with volcanic tuff or mixtures of volcanic tuff and peat moss were fulfilled by artificial chilling and transferring the trees in autumn to $450 \mathrm{~m}$ higher mountain. The trees were trained to the mechanized meadow orchard system. Artificial chilling gave good results than transferring to mountains in terms of leafing, bloom and yield. But, artificial chilling was determined more expensive (Erez et al., 1993).

The result of Dormex $\left(\% 49 \mathrm{H}_{2} \mathrm{CN}_{2}\right)$ and promalin application to Tokaloglu and Karacabey apricots and
Papaz plum bloomed early 2 - 5 days, and 4 - 8 days, respectively, gave good fruit set, fruit weight increased, and harvested 2 - 9 days earlier than control plants (Son and Küden, 2005).

Liu (2018) has reported that Guozhixian and Moorpark apricots varieties are more profitable for producers when they are grown in greenhouses in Liaoning province in China.

Zhai and Liu (2018) have made selection for low chill apricot genotypes to determine early fruit bearing types in greenhouse conditions and Xiajin type were found to be promising for furthers studies in Yuncheng district of Shanxi Province in China

The aim of this research was to induce earliness in fruit production in apricots (Aurora, Ninfa, Roxana) grown in containers in the plastic greenhouse under the Antalya environmental conditions.

\section{MATERIALS and METHODS}

This research was conducted in a plastic greenhouse in the Research and Application Field of Agriculture Faculty of Akdeniz University. The greenhouse was 51 $\mathrm{m}$ long, $18 \mathrm{~m}$ wide and $6 \mathrm{~m}$ high and it was composed of three tunnels. The greenhouse was located at $36^{\circ} 54$ $028^{\prime} \mathrm{N}, 030^{\circ} 38-810^{\prime} \mathrm{E}$ and $38 \mathrm{~m}$ above sea level.

In this research, 1-year old Aurora, Ninfa and Roxana apricot trees grafted on apricot seedling were used.

Drip irrigation was used as an irrigation system and one spaghetti tube (having $2 \mathrm{~L} / \mathrm{h}$ water discharge) was placed in each container.

The trees were planted in 30-liter containers and 60\% peat $+40 \%$ organic manure (sheep manure) was used as the growing media. During planting, the taproot was cut in order to prevent taproot development, and other roots were pruned normally. The trees were planted so that the graft union was $15 \mathrm{~cm}$ above the growing media.

Trees were pruned to an open vase style. During planting, trees were topped at $60 \mathrm{~cm}$ and shoots, which were located in the first $30 \mathrm{~cm}$, were removed. Three to four scaffold branches 5-10 cm apart were evenly distributed in $360^{\circ}$. As a result of branch selection, an open vase style was formed as middle of the canopy stayed open. Then, summer pruning was done in the middle of June until bearing by selecting lateral branches on the scaffold branches and the angle of scaffold branches was set at $45^{-6} 60^{\circ}$ from horizontal. Following that, winter pruning was done in early January every year.

In order to preserve plants from hot weather in summer, the trees were placed in a shade area covered with a net, which transmitted $40 \%$ light. In the second and later years, control, 2.5\% Dormex (contains 49\% $\mathrm{H}_{2} \mathrm{CN}_{2}$, Agrikem), 200 ppm $\mathrm{GA}_{3}$ and artificial chilling (30 days/720 hours at $5^{\circ} \mathrm{C}$ ) treatments were applied. 
Treatments were applied after $15^{\text {th }}$ January every year. Dormex and $200 \mathrm{ppm} \mathrm{GA}_{3}$ treatments were applied with a knapsack sprayer until trees were completely wet. Distilled water was sprayed on control plants with a knapsack sprayer, and subsequently plants were moved to cold storage, which had $80-85 \%$ humidity and $5{ }^{\circ} \mathrm{C}$ temperature for the 30-day holding treatment. At bloom time, bumblebee hives were placed ( 2 hives inside and 1 hive outside of the greenhouse) to insure pollination. After fruit harvest, plants inside and outside of the greenhouse were moved to a $40 \%$ shade area in order to preserve plants from hot summer weather. The plants were held in that area until the treatments for the next year. Following second year of the experiment, the same treatments were done as in the first year.

Fertilization scheduling was prepared according to soil and leaf analysis results and 30 g N.P.K $(15: 15: 15)$ was given to each container using fertigation in early March, April, May and June. Additionally, Fe-EDTA was sprayed to leaves with a knapsack sprayer to prevent chlorosis in plants.

Phenological observations like blooming time, fruit set percentages, harvest time, and yield per plant were made on each tree. Furthermore, pomological analyses like total soluble solids, and titratable acidity were made at harvest.

The experiment was conducted with 3 replications, SAS software was used for statistical analyses of data and comparison of means was done with LSD test.

\section{RESULTS and DISCUSSION}

\section{Bloom time}

The earliest flowering was obtained at the end of February in $2.5 \%$ Dormex treatment, to Ninfa, followed by $2.5 \%$ Dormex applied to Aurora and artificial chilled to Roxana. Treatments induced early flowering more than control. Flowering date lasted 2 5 days depending on the year (Table 1 ).

Table 1. Average flowering dates in apricots

\begin{tabular}{|l|l|c|c|c|}
\hline \multirow{2}{*}{ Cultivars } & Treatments & \multicolumn{3}{|c|}{ Average flowering times } \\
\cline { 2 - 5 } & & First bloom & Full bloom & End of bloom \\
\hline \multirow{5}{*}{ Ninfa } & Control & March 13 & March 15 & March 18 \\
\cline { 2 - 5 } & $2.5 \%$ Dormex & February 26 & March 01 & March 04 \\
\cline { 2 - 5 } & 200 ppm GA 3 & March 02 & March 05 & March 07 \\
\cline { 2 - 5 } & Artificial chilling & March 08 & March 09 & March 12 \\
\hline \multirow{5}{*}{ Aurora } & Control & March 26 & March 27 & March 28 \\
\cline { 2 - 5 } & $2.5 \%$ Dormex & March 10 & March 11 & March 12 \\
\cline { 2 - 5 } & 200 ppm GA 3 & March 13 & March 16 & March 18 \\
\cline { 2 - 5 } & Artificial chilling & March 11 & March 13 & March 16 \\
\hline \multirow{3}{*}{ Roxana } & Control & March 25 & March 26 & March 28 \\
\cline { 2 - 5 } & $2.5 \%$ Dormex & March 17 & March 19 & March 20 \\
\cline { 2 - 5 } & 200 ppm GA 3 & March 19 & March 21 & March 23 \\
\cline { 2 - 5 } & Artificial chilling & March 14 & March 16 & March 18 \\
\hline
\end{tabular}

\section{Fruit set}

The highest fruit set was determined in artificial chilled apricots with $33.96 \%$, and lowest in control with $8.60 \%$. Approximately same results were obtained from $200 \mathrm{ppm} \mathrm{GA}_{3}$ and $2.5 \%$ Dormex applications (Figure 1).

Fruit set rate was significantly higher in Ninfa and Aurora than Roxana, and the highest fruit set rate in Ninfa with $27.54 \%$ (Figure 2).

Fruit set

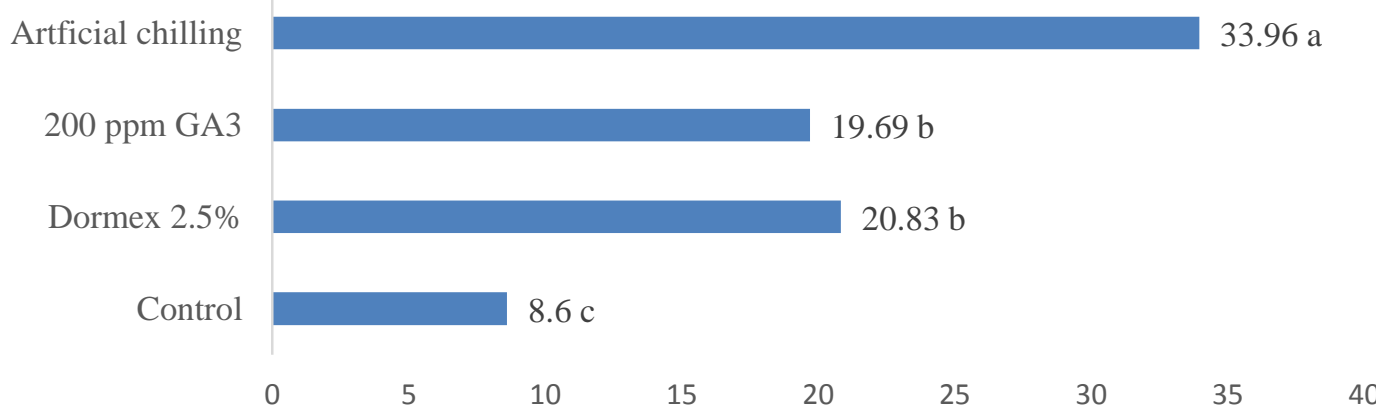

Figure 1. Average fruit set according to applications (LSD\%5: 6.5549). 


\section{Fruit set}

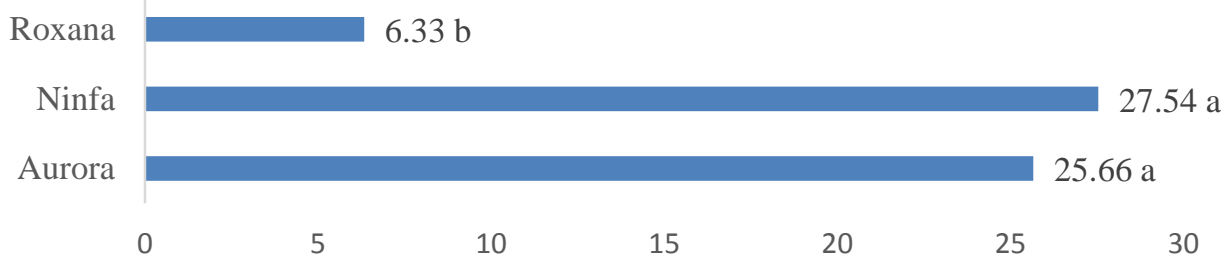

Figure 2. Average fruit set in Aurora, Ninfa and Roxana apricot cultivars (LSD\%5: 5.9467)

\section{Harvest date}

Treatments were matured fruits earlier than control, and the earliest harvest was in Dormex treated apricots, and $200 \mathrm{ppm} \mathrm{GA}_{3}$ and artificial chilling treatments were followed it. Ninfa was matured earlier than Aurora and Roxana. The earliest harvest was done in Ninfa on May 3, and latest was made in Roxana on May 18 (Table 2).

Yield per plant

Treatments were increased yield according to the control. The highest yield was obtained in artificial chilling with $980.44 \mathrm{~g} / \mathrm{plant}$, and lowest in control with $170.63 \mathrm{~g} /$ plant. The results of Dormex 2.5\% and 200 ppm GA3 treatments were not significant (Figure 3).

Among the apricot cultivars, Ninfa showed the highest yield with $1088.84 \mathrm{~g} / \mathrm{plant}$, and yield of Aurora and Roxana were almost the same with 358.50 and 322.62 g/plant, respectively (Figure 4).
Table 2. Average harvest dates in apricot cultivars according to treatments

\begin{tabular}{|l|c|c|}
\hline Cultivars & Treatments & Harvest date \\
\hline Ninfa & Control & May 13 \\
\cline { 2 - 3 } & $2.5 \%$ Dormex & May 03 \\
\cline { 2 - 3 } & 200 ppm GA G $_{3}$ & May 05 \\
\cline { 2 - 3 } & Artificial chilling & May 08 \\
\hline Aurora & Control & May 15 \\
\cline { 2 - 3 } & $2.5 \%$ Dormex & May 04 \\
\cline { 2 - 3 } & 200 ppm GA 3 & May 05 \\
\cline { 2 - 3 } & Artificial chilling & May 08 \\
\hline Roxana & Control & May 18 \\
\cline { 2 - 3 } & $2.5 \%$ Dormex & May 06 \\
\cline { 2 - 3 } & 200 ppm GA 3 & May 07 \\
\cline { 2 - 3 } & Artificial chilling & May 10 \\
\hline
\end{tabular}

\section{Yield}

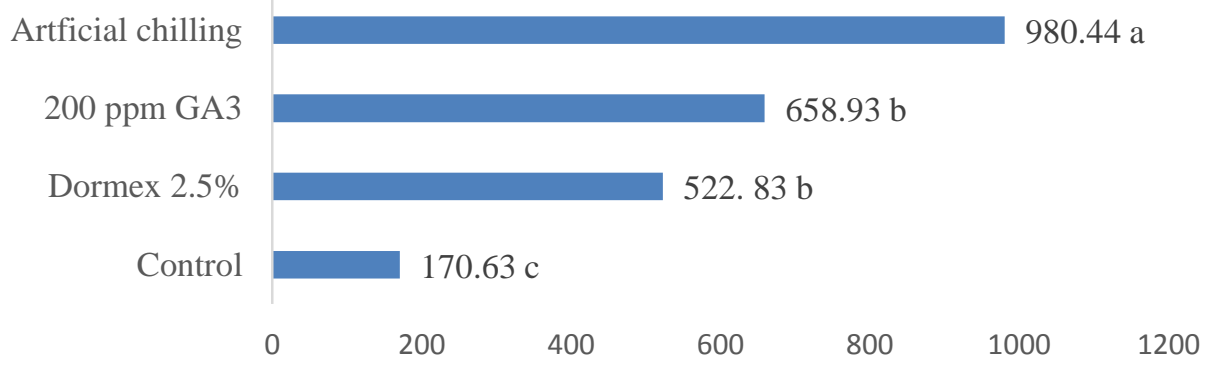

Figure 3. Yield per plant according to the treatments (g/plant) (LSD\%5: 202.65)

Yield

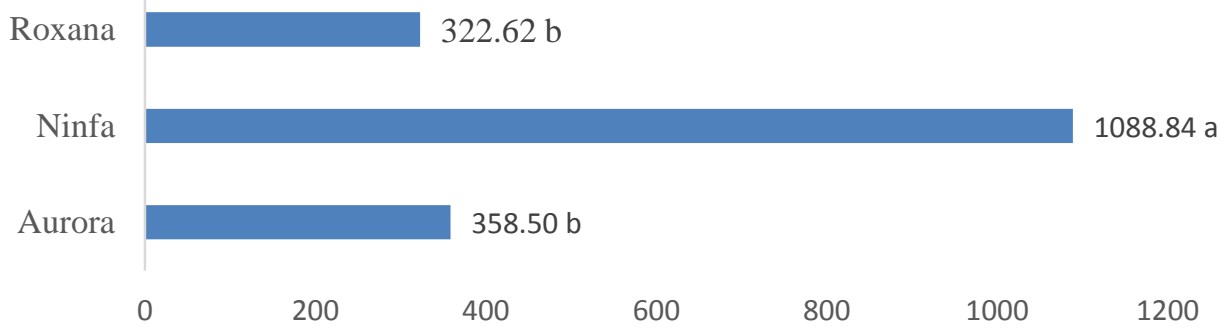

Figure 4. Yield per plant in Aurora, Ninfa and Roxana apricot cultivars (g/plant) (LSD $\% 5: 88.873$ ) 
Soluble solid content

Treatments affected soluble solids content according to control, but soluble content did not change more amongst the treatments, the highest soluble solids content was with 200 ppm GA3 treatment with 14.85 (Figure 5).

Among the apricot cultivars, the highest soluble content was in Roxana with 18.03, followed by Aurora with 16.68 and Ninfa with 11.89, respectively (Figure $6)$.

\section{Titratable acidity}

Treatments increased acidity. The highest acidity was shown in artificial chilling with $1.56 \mathrm{~g} / 100 \mathrm{ml}$, and the lowest was in control with $1.09 \mathrm{~g} / 100 \mathrm{ml}$ (Figure 7).

The highest titratable acidity was in Aurora with 1.61 $\mathrm{g} / 100 \mathrm{ml}$, and lowest in Ninfa with $1.14 \mathrm{~g} / 100 \mathrm{ml}$ (Figure 8).

\section{Soluble content $(\%)$}

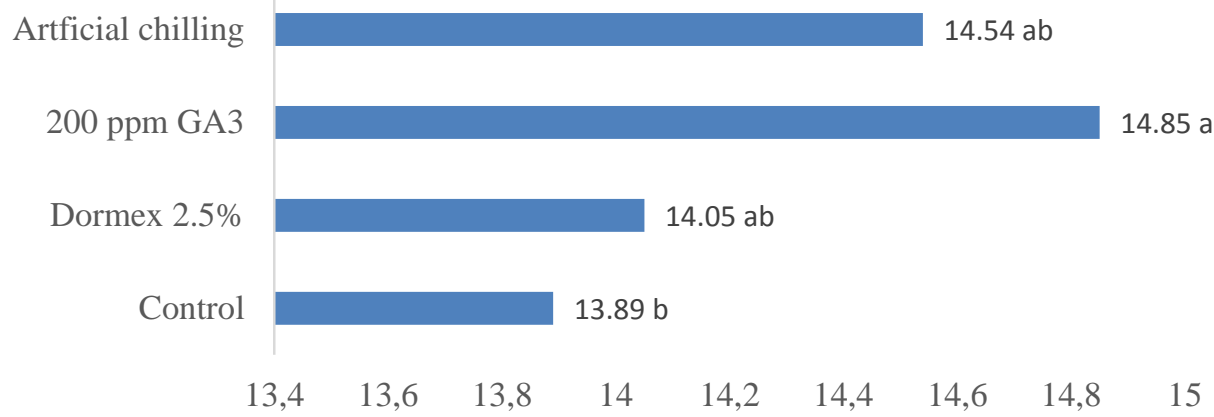

Figure 5. Total soluble content according to treatments (\%) (LSD\%5: 0.9565)

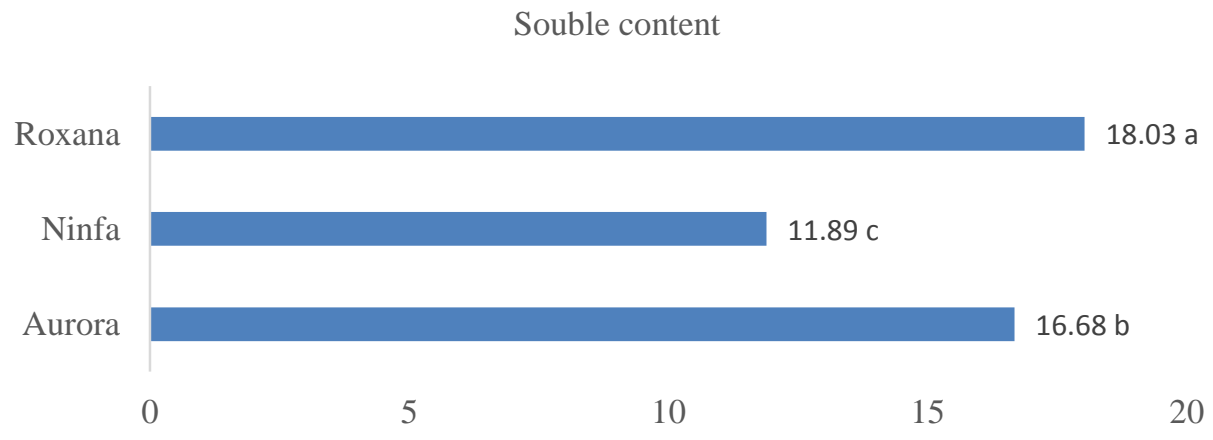

Figure 6. Soluble content in Aurora, Ninfa and Roxana apricot cultivars (\%) (LSD\%5: 0.658)

\section{Titratable acidity}

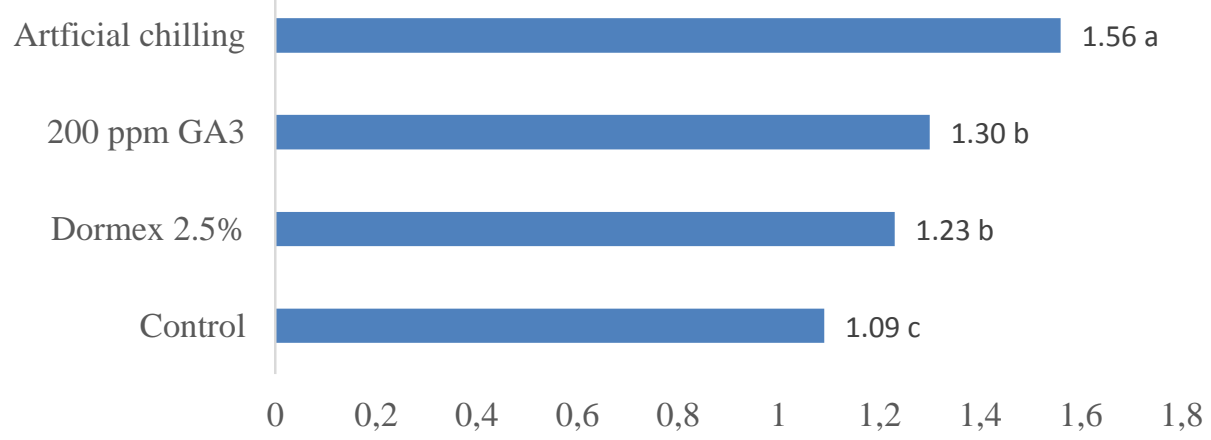

Figure 7. Titratable acidity according to treatments (g/100 ml) (LSD\%5: 0.0955) 
Titretable acidity

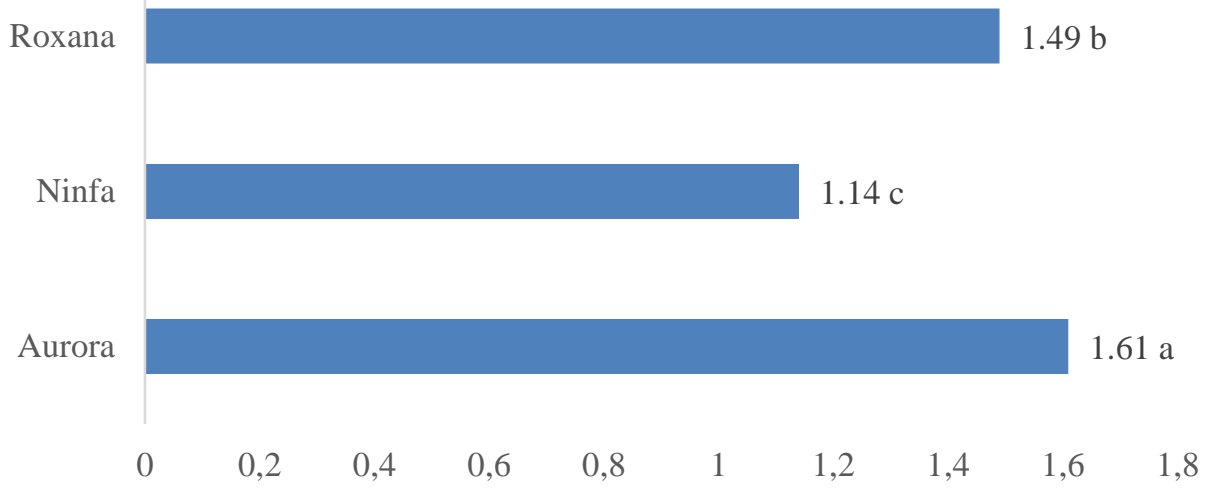

Figure 8. Titratable acidity in Aurora, Ninfa and Roxana apricots (g/100 ml) (LSD\%5: 0.1177)

\section{DISCUSSION}

Some chemicals affected dormancy breaking, early bud break and chilling requirements in many fruits. Dormex and $\mathrm{GA}_{3}$ treated apricots shown early bud break and bloomed higher than control plants (Shulman et al., 1986; Son and Küden, 2005; Westwood, 1993). In the experiment, similar results were obtained, and early bud break and bloom were seen in Dormex\%2.5 and 200 ppm GA 3 treatments. Control plants bloomed later than treatment plants. Environment also had an important role on early bud break and bloom. Untreated Roxana apricots bloomed 19 February in Kahramanmaras which is $150 \mathrm{~km}$ inside from Mediterranean Sea, and has micro climate zone, climatic conditions (Yılmaz, 2002). Nevertheless, in the experiment in Antalya conditions which is near the Mediterranean Sea, control Roxana apricots bloomed early and mid-March. This may be a result from weather temperatures. Because, there was a cold weather in Antalya during the experiment. Thus, Asma and Ozturk (2005) indicated that apricot cultivars can bud break in late February or mid-March according to the years.

Failure to meet the cold demand is a major problem for growing of temperate fruits in the Mediterranean region, and there are some methods to provide chilling such as chemical treatments, cold storage, and transference to high altitudes in pots. Bartolini et al. (1997) determined that Dormex treatment provided chilling requirement and early bud break in apricots. In this experiment, Dormex treatment shown early bloom, but good fruit set and yields was obtained from artificial chilling. The results indicated that cold storage is an appropriate method to achieve chilling requirement.

Ninfa was early blooming cultivar in some experiments (Yllmaz, 2002; Asma, 2012). Similar result was obtained in the experiment, and Ninfa bloomed earlier than Aurora and Roxana.
Fruit set, harvest dates, and yield varies according to years, age, cultivar, self-fertilization capability, pollinator use and environmental conditions. In the experiment, fruit set varied between $6-25 \%$, and the highest fruit set recorded was with $27.35 \%$ in Ninfa from artificial chilled apricots. Polat and Çalışkan (2014) indicated that fruit set rate varied between 2.3$14 \%$ in apricots in Hatay environmental conditions. Çalışkan et al. (2012) harvested Ninfa, Aurora and Roxana in 2,6 and 25 May, respectively. Ninfa was harvested in 26 May in Italy (Bianco et al., 2010) and in 31 May in Kahramanmaras (Yllmaz, 2002). Yield varied between 322.68 and $1.088 .84 \mathrm{~g} / \mathrm{plant}$ in cultivars, and the highest yield was obtained from artificial chilled Ninfa with $1.1150 \mathrm{~g} / \mathrm{plant}$ in the experiment. Similarly, (Yllmaz (2002) obtained 1.018 $\mathrm{g} /$ plant yield from Ninfa. Mratinic et al. (2011) found 4-34 kg yield/plant in apricots, and Uğurluay (2009) determined $4.97 \mathrm{~kg} /$ plant in Hacihaliloglu apricot cultivar in Manisa.

Treatments increased soluble solids content and titratable acidity in apricot cultivars, the highest soluble content and acidity was obtained from $200 \mathrm{ppm}$ GA3 treatment with $14.85 \%$ and artificial chilled treatment with $1.56 \mathrm{~g} / 100 \mathrm{ml}$. Bianco et al. (2010) was $13.8 \%$ soluble content in Ninfa, and Oparnica et al. (2005) measured $1.45 \mathrm{~g} / 100 \mathrm{ml}$ acidity in Ninfa and Aurora. The results of the experiment were consistent with the results of previous experiments researchers.

The results shown that Ninfa can be grown in Antalya environmental conditions without encountering chilling problems. But, Aurora and Roxana cultivars could face with inadequate chilling.

\section{ACKNOWLEDGEMENTS}

This work is part of the Ph.D. experiment and it was financially supported by the Research and Fund of Akdeniz University. 


\section{REFERENCES}

Anonim 2018. Kayısı - T.C. Tarım ve Orman Bakanlığ Araştırma Kuruluşları. https://arastirma.tarimorman.gov.tr > Belgeler > 2018-Temmuz Kayısı

Asma BM 2012. A new early-ripening apricot, 'Dilbay. Hortscience, 47(9): 1367-1368.

Asma BM, Ozturk K 2005. Analysis of Morphological, Pomological and Yield Characteristics of Some Apricot Germplasm in Turkey. Genetic Resources and Crop Evolution, 52: 305-313.

Aşkın A 1989. Ege Bölgesinde Düzenli Meyve Vermeyen Bazı Kayısı Çeşitleri Üzerinde Biyolojik Çalışmalar. Ege Üniveritesi Fen Bilimleri Enstitüsü Bahçe Bitkileri Anabilim Dalı, Doktora Tezi, 133 sy.

Ayanoglu H, Kaska N 1993. Preliminary Results of Local Apricot Adaptation Studies in The Mediterranean Region of Turkey. Acta Horticulturae, 384: 117-122.

Bartolini S, Vitagliano C, Cinelli F, Scalabrelli G 1997. Effect of Hydrogen Cyanamide on Apricot Bud Break and Catalase Activity. Acta Horticulturae, 441: 159-166.

Bianco R, Farina V, Giuseppe I, Filizzola F, Aagozzino P 2010. Fruit Physical, Chemical and Aromatic Attributes of Early, Intermediate and Late Apricot Cultivars. Journal of the Science of Food and Agriculture, 90: 1008-1019.

Calıskan O, Bayazit S, Sumbul A 2012. Fruit Quality and Phytochemical Attributes of Some Apricot (Prunus armeniaca L.) Cultivars as Affected by Genotypes and Seasons. Notulae Botanicae Horti Agrobotanici, 40(2): 284-294.

Erez A, Nir G, Lerner H, Yablowitz Z 1993. Container Grown Peach Trees: Evaluation of a Commercial Endeavor. Acta Horticulturae, 349: 43-47.

Gülcan R, Tekintaş FE, Mısırlı A, Sağlam H, Günver G, Adanacioğlu H 2000. Meyvecilikte Üretim Hedefleri. Türkiye Ziraat Mühendisleri V. Teknik Kongresi, Ankara, s. 587-615.

Liu N 2018. Protected Cultivation of Apricot in Liaoning Province, China. Acta Horticulturae, 1214: 103-108. Doi: 10.17660/ActaHortic. 2018.1214.17

Mratinic E, Popovs Ki B, Milosevic IC T, Popovs Ka M 2011. Evaluation of Apricot Fruit Quality and Correlations Between Physical and Chemical Attributes. Czech Journal of Food Science, 29(2): 161-170.

Oparnica C, Velickovic M, Radivojevic D 2005. Biological and Pomological Characters of The
Introduce Apricot Cultivars in The Region of Belgrade. Voc'arstvo, 39(3): 313-318.

Polat AA, Caliskan O 2014. Fruit Set and Yield of Apricot Cultivars Under Subtropical Climate Conditions of Hatay, Turkey. Journal of Agricultural Science and Technology, 16(4): 863872.

Ran I, Erez A. 1993. Advancement of Ripening of Apricot and Sweet Cherry Preliminary Study With a Mobile Orchard. Acta Horticulturae, 349: 6.

Shulman Y, Nir G, Lavee S 1986. Oxidative Processes in Bud Dormancy and The Use of Hydrogen Cyanamide in Breaking Dormancy. Acta Horticulturae, 179: 141-148.

Son L, Kuden AB 2005. Dormex and Promalin Affects Fruit Set and Earliness of Apricot (Prunus armeniaca) and Plum (Prunus domestica) Cultivars. New Zealand Journal of Crop and Horticultural Science, 33(1): 59-64.

Son L 2018. Bazı Sofralık Kayısı Çeşitlerinin Silifke/Mersin Ekolojik Koşullarındaki Verim ve Kalite Özellikleri Üzerine Araştırmalar. Çukurova Tarım Gıda Bilimleri Dergisi, 33(2): 17-22

Ugurluay D 2009. Karboksil Uygulamasının İhraç Edilen Üzüm, Kayısı, Kiraz Meyvelerindeki Verim ve Kalite Üzerine Etkisi. Çukurova Üniversitesi Fen Bilimleri Enstitüsü Bahçe Bitkileri Anabilim Dalı, Yüksek Lisans Tezi, Adana, 37 sy.

Westwood MN 1993. Hormones and Growth Regulators. Temperate Zone Pomology: Physiology and Culture. Timber Press, Inc. 9999 S.W. Wilshire, Suite 124, Portland, Oregon 97225.

Xianghe Y, Jiayan Z, Weisheng L, Ning L, Feng Z, Yuping Z, Meng S 2004. Varieties and techniques of cultivation of apricot in greenhouse. Journal of Fruit Science, 21(1): 76-78.

Yılmaz KU 2002. Kahramanmaraş'ta Dısssatıma Yönelik Sofralık Kayısı Yetiştiriciliği Üzerine Araştırmalar. Kahramanmaraş Sütçü İmam Üniversitesi Fen Bilimleri Enstitüsü, Bahçe Bitkileri Anabilim Dalı, Yüksek Lisans Tezi, Kahramanmaraş, 89 sy.

Zhai QY, Liu ZH 2018. Breeding of a Fine Apricot Cultivar, 'Xiajin', for Protected Cultivation. Acta Horticulturae, 1214: 199-202. Doi:10.17660/ActaHortic.2018.1214.34

Zhuang WB, Cai BH, Gao ZH, Zhang Z 2016. Determination of Chilling and Heat Requirements of 69 Japanese Apricot Cultivars. European Journal of Agronomy, 74: 68-74. Doi:10.1016/j.eja. 2015.10.006 